\title{
Tsunami waveform analyses of the 2006 underthrust and 2007 outer-rise Kurile earthquakes
}

\author{
Y. Tanioka ${ }^{1}$, Y. Hasegawa ${ }^{2}$, and T. Kuwayama ${ }^{2}$ \\ ${ }^{1}$ Institute of Seismology and Volcanlogy, Hokkaido University, N10W8 Kitaku, Sapporo, Japan \\ ${ }^{2}$ Japan Meteorological Agency, 1-3-4 Otemachi, Chiyoda-ku, Tokyo, Japan
}

Received: 3 August 2007 - Revised: 18 November 2007 - Accepted: 19 November 2007 - Published: 2 January 2008

\begin{abstract}
The 2006 large interplate Kurile earthquake proved that the entire plate interface of the Kurile-Kamchatka subduction zone was strongly coupled from Hokkaido, Japan, to Kamchatka, Russia. The seismic moment of the 2006 Kurile earthquake estimated from ten tsunami waveforms is $3.1 \times 10^{21} \mathrm{Nm}\left(M_{w}=8.3\right)$. This estimate is consistent with the seismic moment estimated from the seismological data in the Global CMT catalog. The computed tsunami propagation indicates that scattering of the tsunami waves occurred at the shallow region near the Emperor Ridge. The computed tsunami propagation also indicates that large later tsunami waves observed at Crescent City is caused by the shallow region along the Mendocino Fracture Zone. The seismic moment of the 2007 outer-rise Kurile earthquake estimated from tsunami waveforms is $1.0 \times 10^{21} \mathrm{Nm}\left(M_{w}=8.0\right)$. This estimate is also consistent with the seismic moment in the Global CMT catalog.
\end{abstract}

\section{Introduction}

On 15 November 2006, a large earthquake occurred off the central Kurile Islands (Fig. 1). The NEIC Preliminary Determination of Epicenters (PDE) provided the source parameters: origin time, 11:14:13.57 GMT; epicenter, $46.59^{\circ} \mathrm{N}$, $153.27^{\circ} \mathrm{E}$. The seismic moment of the earthquake from the Global CMT catalog was $3.31 \times 10^{21} \mathrm{Nm}\left(M_{w}=8.3\right)$. The focal mechanism of the earthquake estimated using the teleseismic body waves (Yamanaka, 2006) showed a thrust fault type $\left(\right.$ strike $=220^{\circ}, \operatorname{dip}=25^{\circ}$, rake $\left.=96^{\circ}\right)$. This indicates that the earthquake was a large interplate event which ruptured the plate interface along the central Kurile subduction zone.

About two month after the 2006 large Kurile earthquake, another large earthquake occurred near the source area of the

Correspondence to: Y. Tanioka

(tanioka@mail.sci.hokudai.ac.jp)
2006 event on 13 January 2007. The NEIC PDE provided the source parameters: origin time, 04:23:21.16 GMT; epicenter, $46.24^{\circ} \mathrm{N}, 154.52^{\circ} \mathrm{E}$. The seismic moment of the earthquake from the Global CMT catalog was $1.6 \times 10^{21} \mathrm{Nm}\left(M_{w}=8.1\right)$. The focal mechanism of the earthquake estimated using the teleseismic body waves (Yamanaka, 2007) showed a normal fault type (strike $=220^{\circ}, \operatorname{dip}=37^{\circ}$, rake $\left.=-108^{\circ}\right)$. The epicenter of this large earthquake was located at the outer-rise in the Pacific plate near the Kurile-Kamchtka Trench. Those indicated that the earthquake was a large tensional outer-rise event which was previously suggested to be occurred after a large interplate earthquake by Christensen and Ruff (1988).

Many large earthquakes have occurred along the KurileKamchatka subduction zone from Kamchatka, Russia, to Hokkaido, Japan, as shown in Fig. 1. The largest earthquake was the 1952 Kamchatka earthquake $\left(M_{w}=9.2\right)$. However, no historical large shallow earthquakes were known in the central Kurile segment (Nichenko, 1991) until the 2006 large Kurile earthquake occurred. Because of no large historical large earthquakes, Nichenko (1991) could not calculate a probability of a large earthquake in this segment, although he noted that this segment should be considered to have high potential of large earthquake qualitatively. Interestingly, Christtensen and Ruff (1988) previously suggested that large compressive stresses should be present at the plate interface because a large compressional outer-rise earthquake occurred opposite side of the central Kurile subduction zone in 1963 $\left(m_{b}\right.$ 7.7). The 2006 interplate Kurile earthquake proved that the suggestion by Christensen and Ruff (1988) was indeed correct, and that the plate interface along the central Kurile subduction zone was strongly coupled.

Two large earthquakes of the 2006 underthrust earthquake and the 2007 outer-rise earthquake generated tsunamis, which propagated through the Pacific Ocean and observed at tide gauge stations along the Pacific coast. Those tsunamis were also observed at ocean bottom pressure sensors operated by NOAA Center for Tsunami Research as a part of the

Published by Copernicus Publications on behalf of the European Geosciences Union. 


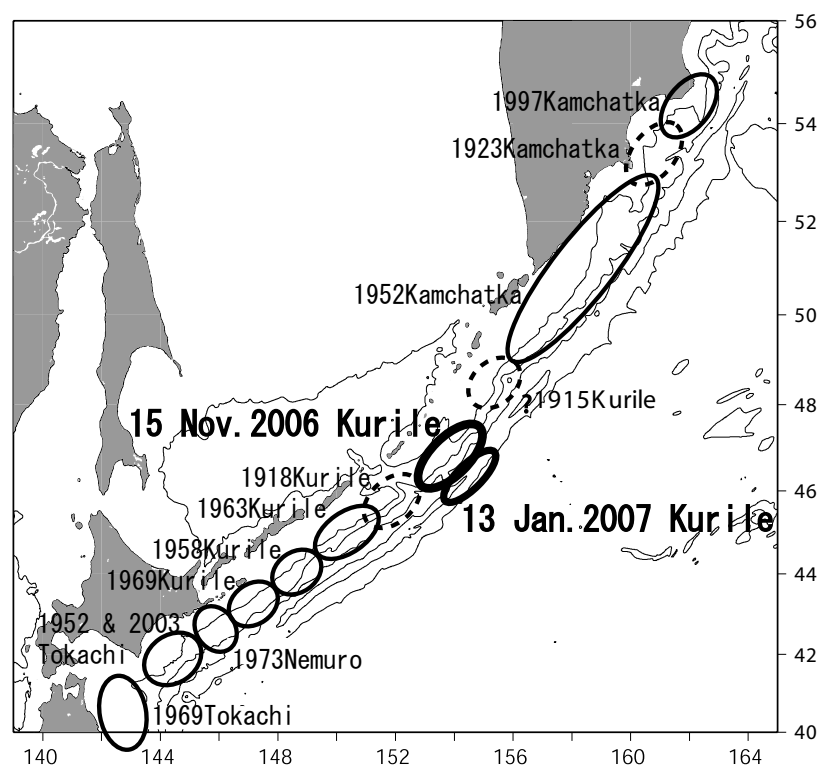

Fig. 1. Source areas of the large earthquakes to rupture the Kurile subduction zone from Hokkaido to Kamchatka during last 100 years. The thick ellipsoid shows the source area of the 2006 interplate Kurile earthquake and the 2007 outer-rise Kurile earthquake.

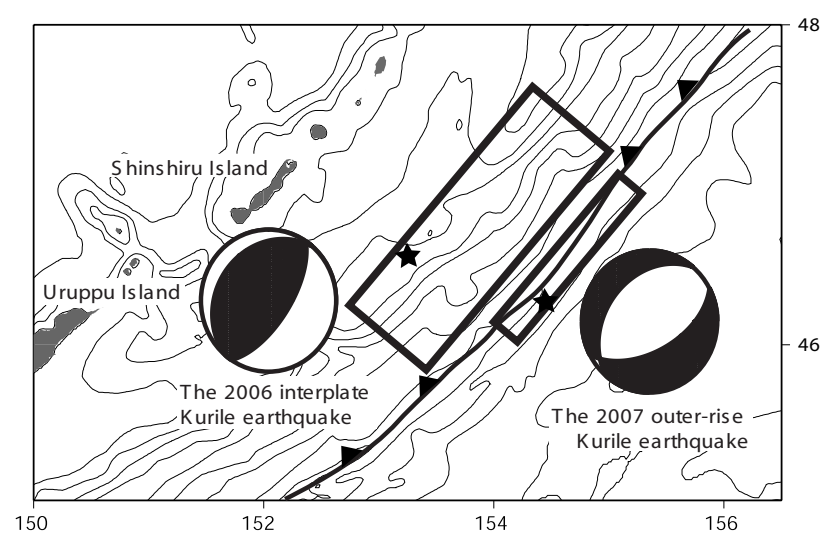

Fig. 2. Fault models for the 2006 and 2007 Kurile earthquakes. The focal mechanisms for two earthquakes are the result from Yamanaka (2007).

real time tsunami monitoring system (Meinig et al., 2005). The 2006 tsunami caused some damages in the port of Crescent City located in the west coast of USA, but not at any cities in Japan or Russia which are located closer to the source region of the earthquake (Rabinovich et al., 2008).

In this paper, we numerically compute the tsunamis due to the 2006 and 2007 Kurile earthquakes to estimate the seismic moments of the earthquakes, and we compare them with the seismic moments previously estimated from the seismological data. We also discuss a reason why a large tsunami was observed only at Crescent City for the 2006 Kurile tsunami.

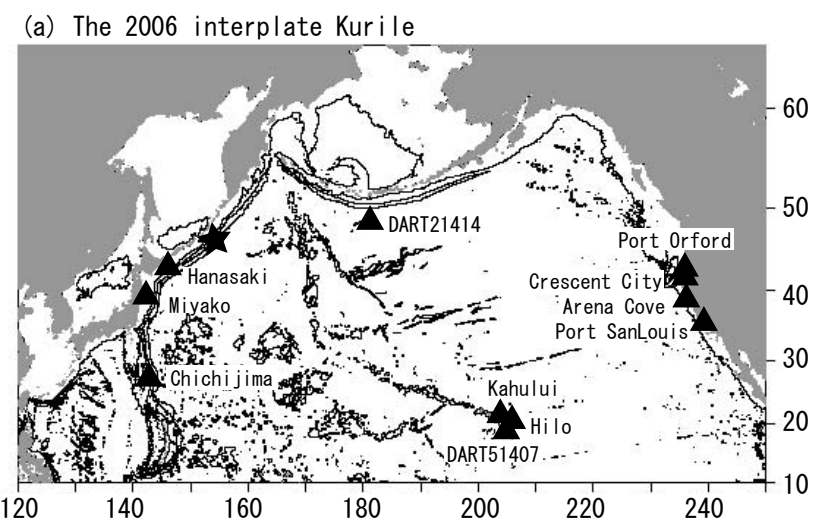

(b) The 2007 outer-rise Kurile

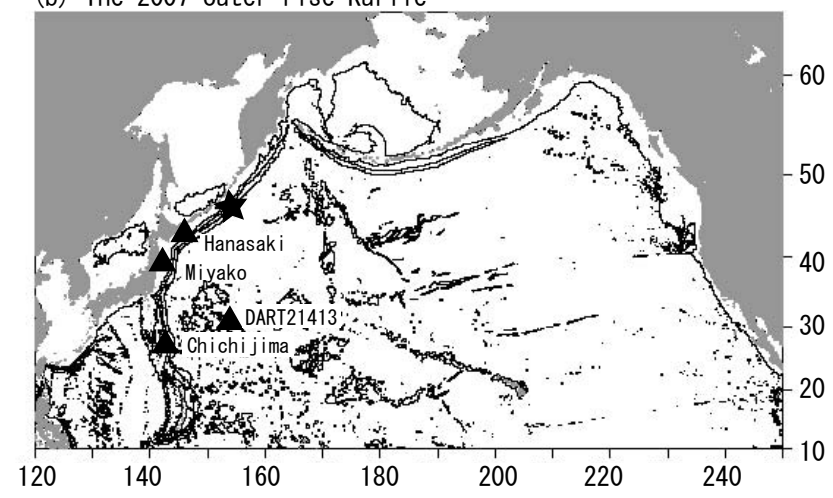

Fig. 3. Locations of tide gauges and ocean bottom pressure systems (DART) used for tsunami analyses for (a) the 2006 interplate Kurile earthquake, and (b) the 2007 outer-rise Kurile earthquake.

\section{Tsunami waveform data and fault models}

For the 2006 underthrust Kurile earthquake, we used 11 tsunami waveforms observed at three tide gauges in Japan, Hanasaki, Miyako, and Chichijima, two tide gauges in Hawaii, Hilo and Kahului, four tide gauges on the west coast of US, Arena Cove, Port Orford, Port San Louis, and Crescent City, and two ocean bottom pressure systems, called DART, off the Aleutian and Hawaiian Islands (Figs. 3a and 4). For the 2007 outer-rise Kurile earthquake, we used four tsunami waveforms observed at three tide gauges in Japan, Hanasaki, Miyako, and Chichijima, and one ocean bottom pressure system shown in Figs. $3 \mathrm{~b}$ and 5.

The fault model of the 2006 large interplate earthquake used to compute tsunami waveforms was a shallow dipping thrust fault $\left(\right.$ strike $=220^{\circ}, \operatorname{dip}=25^{\circ}$, rake $\left.=96^{\circ}\right)$. The fault length and width are $200 \mathrm{~km}$ and $80 \mathrm{~km}$, respectively (Fig. 2). The fault model includes the rupture area of the earthquake estimated using a teleseismic body wave analysis (Yamanaka, 2006). The fault model of the 2007 large outer-rise earthquake is assumed to be a northwest dipping normal fault $\left(\right.$ strike $=220^{\circ}$, dip $=37^{\circ}$, rake $\left.=-108^{\circ}\right)$. The fault length and width are $130 \mathrm{~km}$ and $30 \mathrm{~km}$, respectively (Fig. 2). This fault model also includes the rupture area of the earth- 

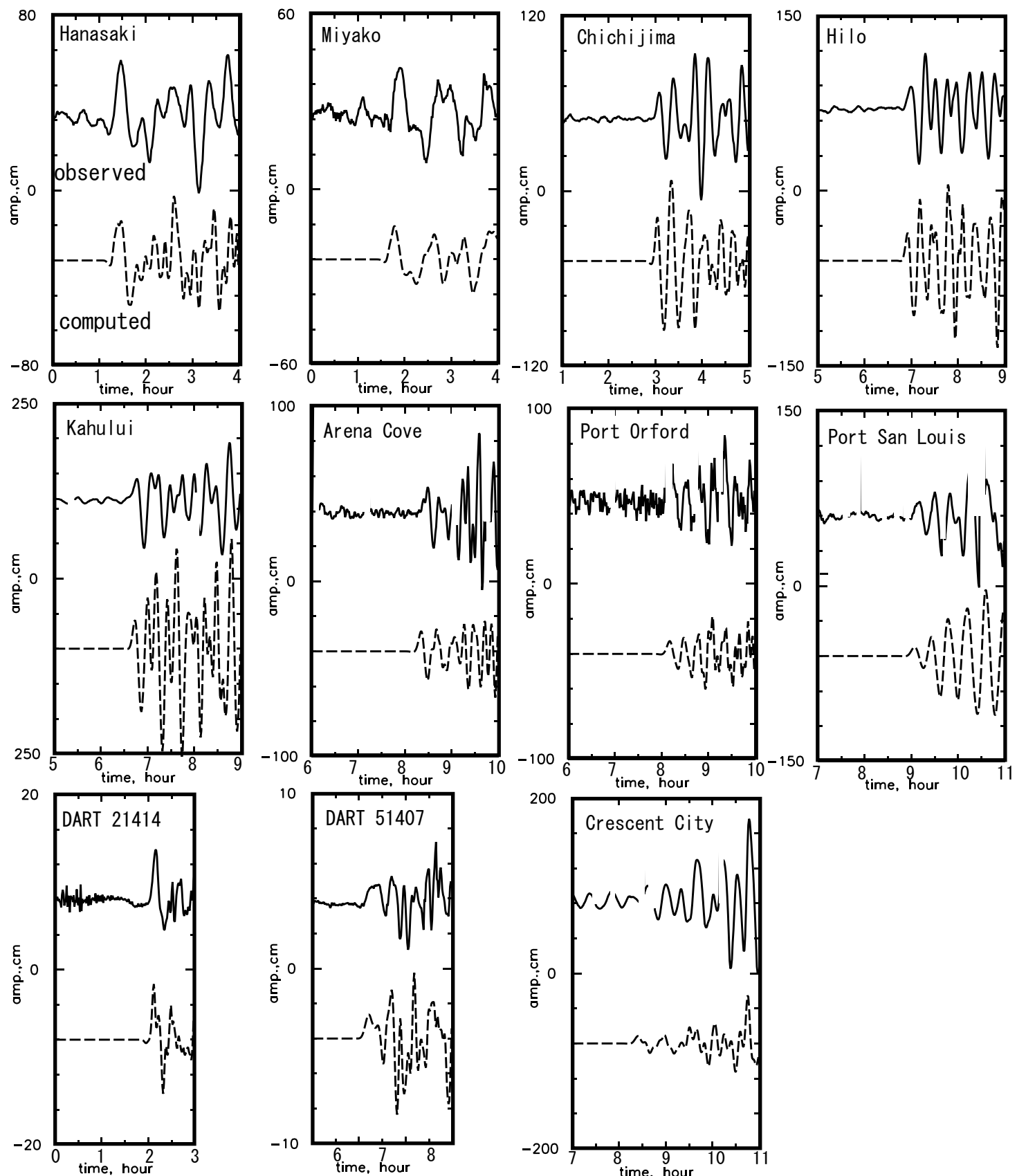

Fig. 4. Comparison of observed (solid) and computed (dashed) tsunami waveforms at nine tide gauges and two ocean bottom pressure systems (DART) for the 2006 interplate Kurile earthquake.

quake estimated using a teleseismic body wave analysis (Yamanaka, 2007).

\section{Tsunami numerical simulation}

In order to compute tsunami propagation, initial water surface deformation must be estimated. In general, the water surface deformation due to faulting of a large earthquake is assumed to be the same as the ocean bottom deformation, because the wavelength of the ocean bottom deformation is much larger than the ocean depth. However, this assumption cannot be applied for the tsunami generated by the 2007 outer-rise earthquake because the fault width is only $30 \mathrm{~km}$ but an ocean depth is about $7 \mathrm{~km}$. Therefore, we compute the water surface initial condition from the ocean bottom deformation using the Kajiura's (1963) equations (see Tanioka 

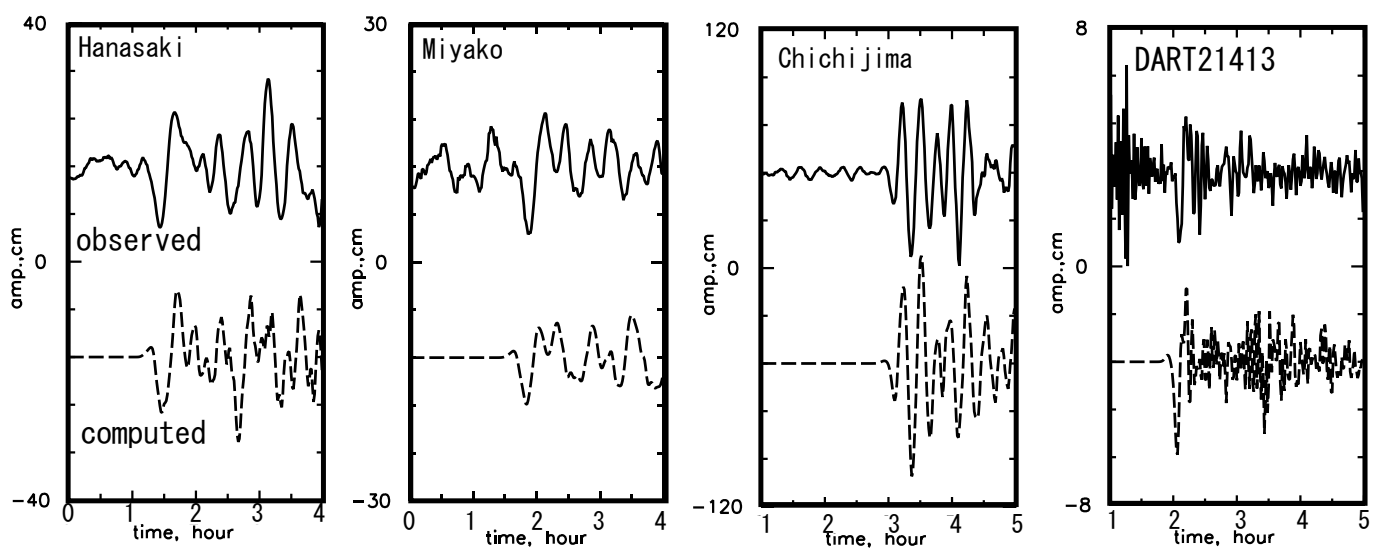

Fig. 5. Comparison of observed (solid) and computed (dashed) tsunami waveforms at three tide gauges and one ocean bottom pressure system (DART) for the 2007 outer-rise Kurile earthquake.

and Seno, 2001). The ocean bottom deformations due to two large Kurile earthquakes are computed from the above fault models using the equations of Okada (1985).

For far field tsunamis, the linear Boussinesq equation should be used in numerical simulations because the dispersion has an effect on the tsunami waveform. However, Imamura et al. (1990) introduced a technique in which the discretization error in the finite difference equation of the linear long wave theory was used to replace the physical dispersion term in the linear Boussinesq equation. In order to use the technique, the grid size must be chosen to make the effects of the discritization and the physical dispersion equal. In this study, a grid size of $5 \mathrm{~min}$ is chosen to compute the tsunami propagation in the Pacific (Fig. 3). Finer grid sizes, $1 \mathrm{~min}$ (about $1.8 \mathrm{~km}$ ) and $20 \mathrm{~s} \mathrm{(about} 0.6 \mathrm{~km}$ ) are used near the tide gauge stations where the dispersion effect is negligible. A detail description of the tsunami numerical simulation is shown in Johnson (1998).

\section{Results}

The comparison of the observed and computed tsunami waveforms for the 2006 large interplate Kurile earthquake is shown in Fig. 4. The slip amount of the fault model (Fig. 2) is estimated by comparing the amplitudes of ten observed initial tsunami waves and computed ones. The tsunami waveform observed at Crescent City is not used to estimate the slip amount because the initial observed tsunami wave is within the noise level although the tsunami has large later phases (Fig. 4). The estimated slip amount from this analysis is $4.8 \mathrm{~m}$. The seismic moment is calculated to be $3.1 \times 10^{21} \mathrm{Nm}$ $\left(M_{w}=8.3\right)$ by assuming that the rigidity near the source area is $4 \times 10^{10} \mathrm{~N} / \mathrm{m}^{2}$. This estimate is consistent with the seismic moment of $3.31 \times 10^{21} \mathrm{Nm}\left(M_{w}=8.3\right)$ from the Global CMT catalog. This indicates that the excitation of tsunami due to the earthquake is well expected from the seismological data.
The comparison of the observed and computed tsunami waveforms for the 2007 large outer-rise Kurile earthquake is shown in Fig. 5. The slip amount of the fault model (Fig. 2) is estimated by comparing the amplitudes of four observed initial tsunami waves and computed ones. The estimated slip amount is $6.4 \mathrm{~m}$. The seismic moment is calculated to be $1.0 \times 10^{21} \mathrm{Nm}\left(M_{w}=8.0\right)$ by assuming that the rigidity near the source area is $4 \times 10^{10} \mathrm{~N} / \mathrm{m}^{2}$. This estimate is also consistent with the seismic moment of $1.65 \times 10^{21} \mathrm{Nm}$ $\left(M_{w}=8.1\right)$ from the Global CMT catalog. All of the observed initial waves for the 2007 tsunami show depression, although the observed initial waves for the 2006 tsunami are positive waves. Those observed negative waves for the 2007 tsunami are well explained by the computed tsunami wave. Those negative initial waves are clearly generated by the subsidence near the source area due to the large tensional earthquake with a normal fault type mechanism.

\section{Discussions}

Eight snapshots of the computed tsunami propagation for the 2006 large interplate Kurile earthquake and the bathymetry around the Pacific Ocean are shown in Fig. 6. At 1 and $2 \mathrm{~h}$ after the earthquake occurred, large tsunami waves propagate toward the southeast direction from the source and only small tsunami waves propagate toward Japan or Kamchatka.

At 3, 4, and $5 \mathrm{~h}$ after the earthquake occurred, large tsunami waves scatter at the shallow region located in the most southern part of the Emperor Ridge system. A part of that scattered tsunami propagates toward Japan or the west coast of USA. This should be one of reasons that large later phases were observed at tide gauges in Japan (Japan Meteorological Agency, 2007). The tsunami generated by the 1994 large Kurile earthquake also caused the similar scattering near the Emperor Ridge system (Tanioka, 2005). 

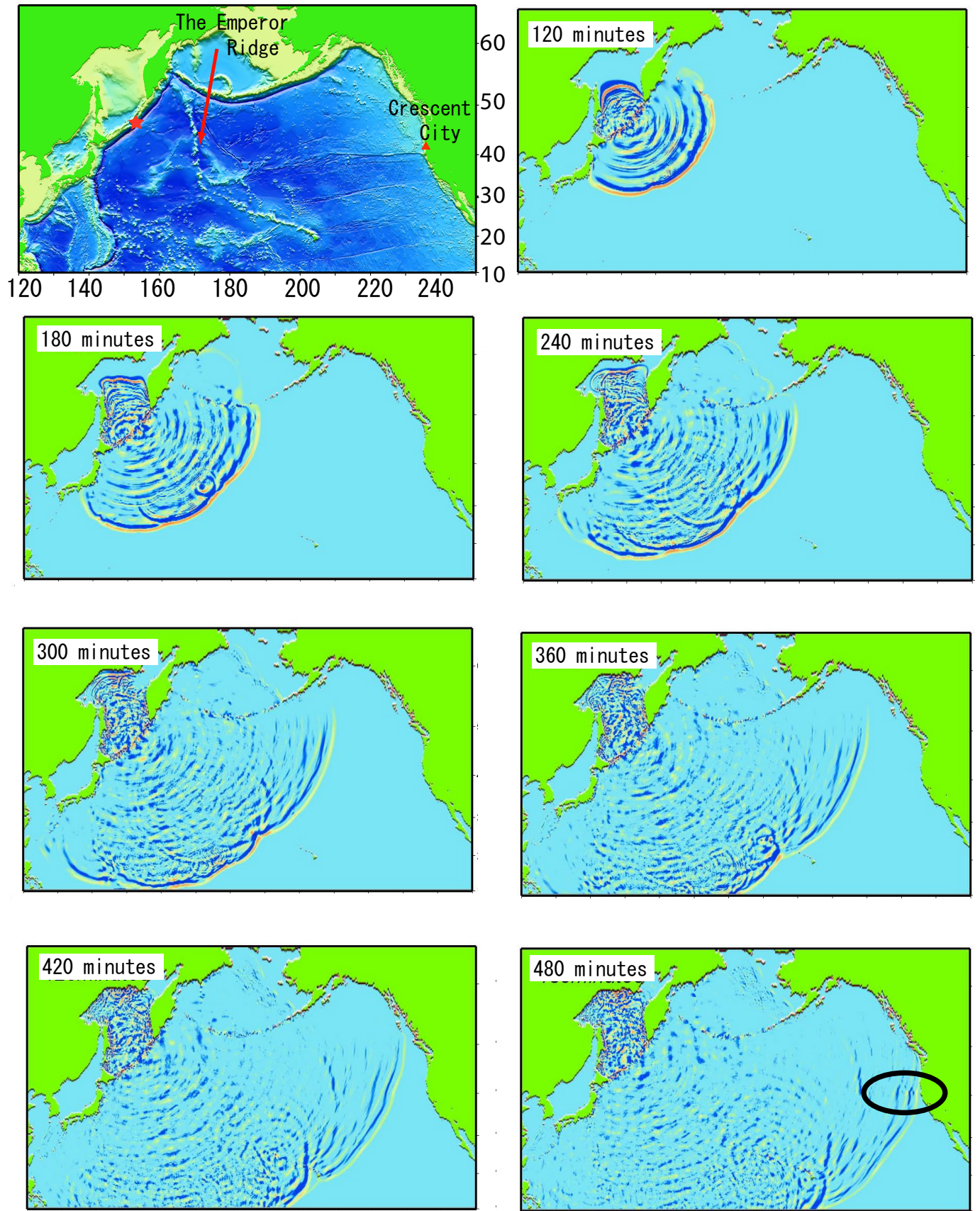

Fig. 6. Bathymetry around Pacific and seven snapshots of the tsunami propagation of the 2006 Kurile tsunami. The snapshots are taken 2,3 , $4,5,6,7$, and $8 \mathrm{~h}$ after the origin time of the 2006 Kurile earthquake. An ellipsoid shows the large tsunami off Crescent City.

At 6 and $7 \mathrm{~h}$ after the earthquake, large tsunamis continue to propagate toward southwest and reached the Hawaiian Islands. The tsunami propagates continuously toward the west. At $8 \mathrm{~h}$ after the earthquake, the tsunami reaches the west coast of USA. We can see that the later tsunamis off Crescent City were much larger than those off other parts of the west coast (an ellipsoid in Fig. 6). Those large later phases are caused by the shallow area along the Mendocino Fracture
Zone off Crescent City. This should be one of reasons that the 2006 Kurile tsunami caused some damages in the port of Crescent City, but not in the other cities along the west coast of USA. Another reason may be a local resonant effect of the harbor in Crescent City. 


\section{Conclusions}

The 2006 large interplate earthquake proved that the plate interface along the entire Kurile-Kamchatka subduction zone was coupled from Hokkaido to Kamchatka as shown in Fig. 1. The seismic moment of the 2006 Kurile earthquake estimated from the tsunami waveforms observed at eight tide gauges and two ocean bottom pressure systems (DART) was $3.1 \times 10^{21} \mathrm{Nm}\left(M_{w}=8.3\right)$. This estimate was consistent with the seismic moment from the Global CMT catalog. The snapshots of the computed tsunami propagation indicated that the scattering of the tsunami waves occurred at the shallow region near the Emperor Ridge. The snapshots also indicated that large later tsunami waves observed at Crescent City was caused by the shallow region along the Mendocino Fracture Zone off Crescent City.

The seismic moment of the 2007 outer-rise Kurile earthquake estimated using four tsunami waveforms was $1.0 \times 10^{21} \mathrm{Nm}\left(M_{w}=8.0\right)$. This estimate was also consistent with the seismic moment from the Global CMT catalog. The tsunami simulation indicated that negative initial observed tsunamis were generated by the subsidence near the source area due to the large tensional earthquake with a normal fault type mechanism.

Acknowledgements. We thank one of two reviewers, A. Rabinovich, for helpful comments to improve our manuscript. This work was partially supported by the Grants-in-Aid for Scientific Research in Japan (C:17540386).

Edited by: P. Fabian

Reviewed by: A. Rabinovich and another anonymous referee

\section{References}

Christensen, D. H. and Ruff, L. J.: Seismic Coupling and Outer Rise Earthquakes, J. Geophys. Res., 93(B11), 13 421-13 444, 1988.

Imamura, F., Shuto N., and Goto, C.: Study on the numerical simulation of the transoceanic propagation of tsunami, Zisin, 2, 389402, 1990 (in Japanese).

Japan Meteorological Agency: The earthquake that occurred in Kuril Islands on November 15, 2006, The REPORT of CCEP, 77, 437-449, 2007 (in Japanese).

Johnson, J. M.: Heterogeneous coupling along Alaska-Aleutians as inferred from tsunami, seismic, and geodetic inversions, Adv. Geophys., 39, 1-110, 1998.

Kajiura, K.: The leading wave of a tsunami, Bull. Earth. Res. Inst. Univ. Tokyo, 41, 535-571, 1963.

Meinig, C., Stalin, S. E., Nakamura, A. I., González, F., and Milburn, H. G.: Technology Developments in Real-Time Tsunami Measuring, Monitoring and Forecasting, in: Oceans 2005 MTS/IEEE, available online: http://nctr.pmel.noaa.gov/Dart/ Pdf/mein2836_final.pdf, 2005.

Nichenko, S. P.: Circum-Pacific seismic potential, 1989-1999, Pure Appl. Geophys., 133, 169-259, 1991.

Okada, Y.: Surface deformation due to shear and tensile faults in a half-space, Bull. Seism. Soc. Am., 75, 1135-1154, 1985.

Rabinovich, A. B., Lobkovsky, L. I., Fine, I. V., Ivelskaya, T. N., Thomson, R. E., and Kulikov, E. A.: Near-source observations and modeling of the Kuril Islands tsunamis of 15 November 2006 and 13 January 2007, Adv. Geosci., 14 (this special volume), 2008.

Tanioka, Y.: Pacific-wide Tsunamis due to 1994 Kurile Earthquake (Mw 8.3), Geophys. Bull. Hokkaido Univ., 68, 191-197, 2005 (in Japanese).

Tanioka, Y. and Seno, T.: Sediment effect on tsunami generation of the 1896 Sanriku tsunami earthquake, Geophys. Res. Lett., 28, 3389-3392, 2001.

Yamanaka, Y.: http://www.eri.u-tokyo.ac.jp/sanchu/Seismo_Note/ 2006/EIC183.html, 2006.

Yamanaka, Y.: http://www.eri.u-tokyo.ac.jp/sanchu/Seismo_Note/ 2007/EIC184.html, 2007. 